\title{
Molecular characterization of urdbean (Vigna mungo) germplasm related to resistance against urdbean leaf crinkle virus
}

\author{
R. Binyamin', M. Aslam Khan', A.I. Khan², M. Azam Khan', F.S. Awan ${ }^{2}$ \\ and N.A. Khan ${ }^{1}$ \\ ${ }^{1}$ Department of Plant Pathology, University of Agriculture, Faisalabad, Pakistan \\ ${ }^{2}$ Centre of Agricultural Biochemistry and Biotechnology, University of Agriculture, \\ Faisalabad, Pakistan \\ ${ }^{3}$ PMAS-Arid Agriculture University, Rawalpindi, Pakistan \\ Corresponding author: R. Binyamin \\ E-mail: ranabinyamin@yahoo.com \\ Genet. Mol. Res. 10 (3): 1681-1688 (2011) \\ Received April 18, 2011 \\ Accepted July 27, 2011 \\ Published August 8, 2011 \\ DOI http://dx.doi.org/10.4238/vol10-3gmr1446
}

\begin{abstract}
Urdbean (Vigna mungo) is an important pulse crop grown worldwide. Urdbean leaf crinkle virus (ULCV) is a pathogen of urdbean found in Pakistan that causes huge losses in yield. Forty urdbean varieties/lines were screened against the virus under field conditions during spring season 2009. None of the lines appeared to be highly resistant or resistant. On the basis of a 0-5 disease rating scale and disease severity index, genotypes varied significantly in their reaction to ULCV. Four lines (M-6206, IAM-382-15, IAM133, and Mash-1) were moderately resistant, eight were rated as moderately susceptible, and 21 as susceptible; the remaining seven lines were highly susceptible. RAPD analyses revealed an extensive amount of variation, which could be used for cultivar identification. Genetic differentiation among urdbean genotypes was similar to the field screening data. The varieties 6065-3 and 6206 were highly susceptible and moderately resistant, respectively, to ULCV under
\end{abstract}


field conditions, confirmed by the RAPD analysis. These varieties were the most diverse varieties in the similarity matrix $(67.2 \%)$, while the varieties IAM-382-9 and 07M003 were the most similar (98.4\%). This information will help in the recognition of available resistant germplasms that can resist this disease and will be utilized for urdbean improvement in Pakistan.

Key words: Urdbean; ULCV; RAPD analysis; Germplasm

\section{INTRODUCTION}

Urdbean or mash, also called blackgram (Vigna mungo (L.) Hepper) is native to India. From India, it has spread to many countries, including Pakistan. It is relatively more susceptible than other pulses to leaf crinkle disease caused by urdbean leaf crinkle virus (ULCV) (Kadian, 1980; Bashir et al., 2005; Ashfaq et al., 2007). Among the viral diseases, ULCV is considered to be the most serious, depending on the season and variety cultivated (Reddy et al., 2005). In Pakistan, the virus has been reported to decrease grain yield from 35 to $81 \%$, depending on genotype and time of infection (Bashir et al., 1991). In Pakistan, it covers an area of 31,500 hectares, yielding an annual production of 13.7 thousand tons of grain with a $20.8 \%$ decrease in production as compared to the preceding year (Anonymous, 2009). The use of disease-resistant crop varieties is regarded as an economical method for controlling plant diseases, especially those caused by viruses. A good deal of research has been directed towards screening urdbean germplasm against ULCV to identify resistant sources under diverse environmental conditions, and a number of lines resistant to virus have been selected (Iqbal et al., 1991; Bashir et al., 2005).

One of the best possibilities is the genetic marker system to find out the genetic variation. With the establishment of DNA markers and sequencing technology, the genetic sequencing of various important plants and animals has been accomplished (Jinguo and Brady, 2003). Up to now, the study on genetic diversity of urdbean on the basis of DNA markers was not significant (Sivaprakash et al., 2004). Past studies showed that DNAbased markers used in the study of genetic variation of various Vigna species were not up to their potential use (Amadou et al., 2001).

A large number of molecular marker techniques have been employed to quantify the genetic divergence of a range of organisms. The random amplified polymorphic DNA (RAPD) marker technique was first introduced by Williams et al. (1990). The genetic diversity studies on the basis of RAPD markers were mostly used because they are simple and relatively inexpensive (Harris, 1999). RAPD analysis was found to be easy and most effective for genetic variation studies in several Vigna species, including blackgram studies by Kaga et al. (1996) and cowpea genetic variation studies by Mignouna et al. (1998), while RAPD markers were also used by Santalla et al. (1998) in the genetic diversity studies of mungbean. Yee et al. (1999) also reported excellent results of RAPD markers in the case of adzuki bean genetic variation studies.

Introducing disease-resistant varieties is regarded as the most economical and durable method for controlling plant diseases, especially those caused by viruses. A good deal of research has been directed towards screening urdbean germplasm against ULCV, to identify 
resistant sources under diverse environmental conditions, and a number of lines resistant to the virus were selected (Iqbal et al., 1991; Bashir et al., 2005). They all suggested continuing screening of available varieties and new germplasm, which constitutes the basis of this study. Therefore, 40 urdbean genotypes of diverse origins were evaluated in this study against ULCV in spring epiphytotic conditions. In the past, only field screening of the urdbean varieties/ lines was done, which was based on disease symptoms. The aim of the present study was to determine the genetic variation in urdbean via RAPD analysis to know whether these varieties/ lines, which differ in field screening results, also vary on a genetic basis.

\section{MATERIAL AND METHODS}

To catalogue urdbean genotypes, an urdbean disease screening nursery was established in the Research Area of the Department of Plant Pathology, University of Agriculture Faisalabad (UAF). Each test entry was planted in a row of $3 \mathrm{~m}$ in length and spaced $30 \mathrm{~cm}$ apart and replicated three times. One row of the most susceptible check (Kabali mash) was repeated after every two entries in the experiment. The spread of ULCV in the experimental plot was recorded at 7-day intervals until maximum infection was achieved. Plants showing ULCV disease symptoms such as crinkling, curling, puckering, rugosity, and enlargement of the leaves were counted and percent infection was calculated. Disease incidence rating was based on a 0-5 arbitrary scale (Table 1), as suggested by Ashfaq et al. (2007). The number of genotypes infected per week was calculated.

\begin{tabular}{|c|c|c|}
\hline Disease reaction & Disease severity index (DSI) & Reaction \\
\hline All plants free of symptoms & 0 & HR \\
\hline $1-10 \%$ plants infected showing mild crinkling at the top, pods normal & 1 & $\mathrm{R}$ \\
\hline $11-20 \%$ plants infected showing crinkling and curling of top leaves, pods normal & 2 & MR \\
\hline $21-30 \%$ plants infected with crinkling, puckering, malformation, shortening of pods & 3 & MS \\
\hline $31-40 \%$ plants infected showing all the typical disease symptoms & 4 & $\mathrm{~S}$ \\
\hline $\begin{array}{l}\text { More than } 40 \% \text { plants infected, with all plants showing severe symptoms, } \\
\text { few pods containing few seeds }\end{array}$ & 5 & HS \\
\hline
\end{tabular}

Ten urdbean varieties/lines were selected from field screening results, and seeds of urdbean germplasm were planted in pots (Table 2). Fresh leaf samples (8-10) from potted urdbean plants were collected two weeks after germination and immediately stored at $-80^{\circ} \mathrm{C}$ for molecular studies. DNA from these samples was extracted following a modified CTAB method for DNA extraction (Khan et al., 2004). The concentration of DNA was determined by Gene Quant and working dilutions were optimized on the basis of the best amplification. RAPD profiles were obtained for urdbean germplasm. Fifteen RAPD primers (Table 3) were used in polymerase chain reaction (PCR). The bands were counted and data were analyzed using the Popgen 32 computer software (ver. 1.44), and the genetic variation and similarity were assessed. The genetic relationship between the urdbean plants was determined by clustering the genotypes. 


\begin{tabular}{l}
\multicolumn{2}{c}{ Table 2. Urdbean genotypes of Vigna munga of local origin. } \\
\hline Sample No.
\end{tabular}

$\mathrm{MR}=$ moderately resistant; $\mathrm{S}=$ susceptible; $\mathrm{MS}=$ moderately susceptible; $\mathrm{HS}$ = highly susceptible.

Table 3. Detail of RAPD primers along with their sequences used in the study.
\begin{tabular}{lllcll}
\hline Serial. No. & Primer name & Sequence & Serial. No. & Primer name & Sequence \\
\hline 1 & GL DecamerI-02 & GGAGGAGAGG & 9 & GL DecamerJ-13 & CCACACTACC \\
2 & GL DecamerI-03 & CAGAAGCCCA & 10 & GL DecamerJ-1 & TGTAGCAGGG \\
3 & GL DecamerI-06 & AAGGCGGCAG & 11 & GL DecamerJ-20 & AAGCGGCCTC \\
4 & GL DecamerI-07 & CAGCGACAAG & 12 & GL DecamerK-05 & AAGCCCGAGG \\
5 & GL DecamerI-09 & TGGAGAGCAG & 13 & GL DecamerK-07 & AGCGAGCAAG \\
6 & GL DecamerI-20 & AAAGTGCGGG & 14 & GL DecamerK-10 & GTGCAACGTG \\
7 & GL DecamerJ-04 & CCGAACACGG & 15 & GL DecamerK-15 & CTCCTGCCA \\
8 & GL DecamerJ-10 & AAGCCCGAGG & & & \\
\hline
\end{tabular}

\section{RESULTS AND DISCUSSION}

\section{Screening of urdbean germplasm}

Mild to severe specks were first observed on young leaves, and then rugosity and curling of leaves appeared. The severity of disease increased with the passage of time based on the expression of symptoms. The spread of ULCV disease in all urdbean lines was recorded at 1-week interval for seven weeks after germination. Wavy appearance on the third trifoliate leaves followed by crinkling, rugosity and puckering of leaves, shortening of petioles and crowding of leaves were observed on the susceptible check (kabuli mash) 15 to 20 days after germination. Infected plants were counted and percent disease increment calculated on each occasion.

None of the lines appeared to be highly resistant (HR). Four lines (M-6206, IAM-382-15, IAM-133, and Mash-1) were rated as moderately resistant (MR); eight were rated as moderately susceptible (MS) and 21 as susceptible (S), and the remaining seven lines were highly susceptible (HS) (Table 4). Identification of resistant germplasm against ULCV has been reported by Ashfaq et al. (2007), Chaudhry et al. (2007), Bashir and Zubair (2002), and Singh (1980), who evaluated a number of urdbean lines/cultivars against ULCV and found good resistance only in a few lines.

In the first week, 34 of 40 urdbean lines were infected by ULCV. This represents $85 \%$ of germplasm being infected at a very early stage. ULCV infection in this period ranged between 0 and $28 \%$ with a mean of $9.9 \%$. Maximum infection was observed in varieties/lines ES-1 (28\%), 6065-3 (24\%) and 6049-20 (24\%) and minimum infection in the varieties/lines IAM-382-15, Mash-1, Chakwal Mash PD-L-Vo5, 6036-7, M-6206, and $07 \mathrm{M} 006$, i.e., $0.00 \%$. The disease progressed and spread rapidly in the 2 nd week as none 
Table 4. Response of urdbean germplasm to natural infection by urdbean leaf crinkle virus.

\begin{tabular}{|c|c|c|c|}
\hline Resistance level & Number of genotypes & Disease severity & Varieties/lines \\
\hline MR & 4 & 2 & IAM-382-15, IAM-133, Mash-1, M-6206 \\
\hline MS & 8 & 3 & $\begin{array}{l}\text { IAM-382-1, IAM-382-9, IAM-5-60, } \\
\text { Local-2, 95024, 6049-1, 6036-7, 6065-1 }\end{array}$ \\
\hline $\mathrm{s}$ & 21 & 4 & $\begin{array}{l}\text { IAM-3340, IAM-3, Chakwal mash, } \\
\text { Chakwal mash PD-L-Vo5, AARIM-32, } \\
\text { Mash-97, Mash-189, Mash-17, Fsd. Local, } \\
\text { 95009, 95017, 6036-1, 6036-14, 6065-5, } \\
\text { 6036-24, 07M002, 07M003, 07M004, } \\
\text { 07M005, 07M006, 07M007 }\end{array}$ \\
\hline HS & 7 & 5 & ES-1, 6049-20, 6036-12, 6036-21, 6065-3, 62027, 95019 \\
\hline
\end{tabular}

$\mathrm{MR}=$ moderately resistant; $\mathrm{MS}$ = moderately susceptible; $\mathrm{S}=$ susceptible; HS = highly susceptible.

of the test entries escaped ULCV infection; all urdbean lines were found to be infected and none of the lines remained asymptomatic, with the range of ULCV infection ranging from $4-36 \%$ and the mean infection observed being $12.1 \%$.

In the third week of observation, the disease symptoms became highly conspicuous. Disease incidence ranged $8-44 \%$ with a mean of $21.1 \%$, revealing an increment of $9 \%$ over previous weeks. In the 4 th week of observation, $100 \%$ of test entries continued to be infected. The disease incidence was between 8 and $60 \%$ with an average incidence of $25.7 \%$, i.e., $4.6 \%$ increased over previous observations. It was $12-68 \%$ with an average of $30.6 \%$ in the fifth observation and $8-68 \%$ with a mean of $35 \%$ incidence in the sixth observation. In the seventh week of observation, it was $12-76 \%$ with a mean of $38.2 \%$, and thus, almost all the test lines fell far below the limits of resistance.

The results clearly indicated that in the initial period of 4 weeks urdbean crop is highly critical for the development and spread of ULCV. Field environment was highly conducive for natural spread of the disease due to high vector population and the buildup of inoculum potential of virus from the very beginning. One main problem in germplasm evaluation is that some genotypes found to be resistant at one location turned out to be susceptible at another place (Iqbal et al., 1991; Bashir et al., 2005), and therefore, environmental genotype interaction and genetic diversity should also be studied for durable resistance. It also indicates that there are minimum chances that any disease escape mechanism could become operative, except the changes in environmental factors.

\section{Molecular characterization of urdbean genotypes}

Ten urdbean genotypes were analyzed by 15 RAPD decamers (Tables 2 and 3). Each primer-template produced distinct, easily detectable bands of variable intensities. Indistinct bands were considered as non-specific amplification and these were ignored. Considering all the primers and urdbean genotypes, a total of 61 bands were amplified in the PCRs of 10 genotypes, of which 30 were polymorphic, showing $49 \%$ overall polymorphism. The number of polymorphic bands per primer was higher (2) than that obtained by Souframanien and Gopalakrishna (2004), who found 1.8 polymorphic bands per primer but lower than 4.43 to 8.94 , which was obtained by Dikshit et al. (2007) (Figure 1). The level of polymorphism observed 


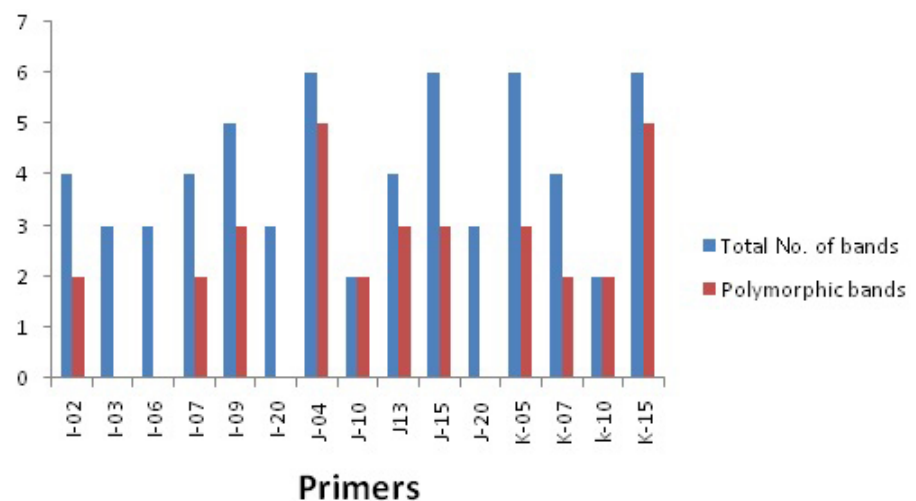

Figure 1. Number of polymorphic bands per primer.

in urdbean is comparable to the reports of several RAPD studies by various authors (Ghaffor et al., 2001; Souframanien et al., 2002; Arulbalachandran et al., 2009). The number of bands produced per genotype ranged from 47 to 61 with an average of 53 bands per genotype (Figure 2). Urdbean accession 6049-20 produced the maximum number of bands (61), while IAM-133 gave the minimum number of bands (47).

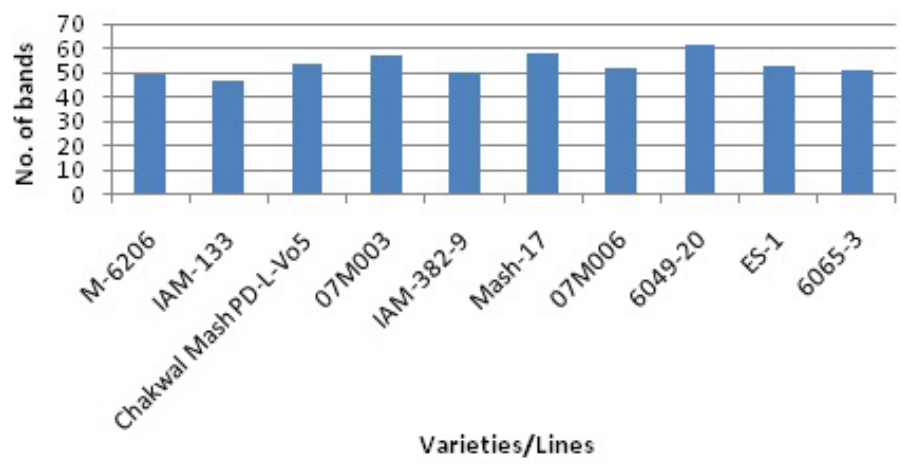

Figure 2. Number of bands per genotype.

The low degree of similarity (monomorphic bands) indicated high divergence between the varieties. The number of amplification products produced per primer varied between 2 and 6 with an average of 4 bands per primer. The maximum number of fragments was produced by the primers GLJ-04 (6), GLJ-15 (6) and GLK-05 (6), while the lower frequency of fragments was found with the primers GLK (2) and GLJ (2).

The PCR amplification results for different urdbean varieties using the GLK-07 primer showed variable banding pattern for disease response. The gel picture (Figure 3) showed that genotypes 1-5 had almost similar banding patterns with minimum variability. For genotypes M-6206 and IAM-133, which were considered MR from field screening, the results showed 3 bands of approximately 200, 600 and 900 bp. Genotypes Chakwal Mash PD2-L-V05, 07M003 and IAM-382-9 also showed some additional bands of approximately 450 and $630 \mathrm{bp}$, which 
were considered MS and S from field screening. On the other hand, the genotypes M-17, 07M006, M-6049-20, ES-1, and M-6065-3, which were S and HS in field screening, showed 3 bands, having sizes of 400, 600 and $900 \mathrm{bp}$. Only one band of $400 \mathrm{bp}$ was observed to be different from MR, S and MS genetic patterns.

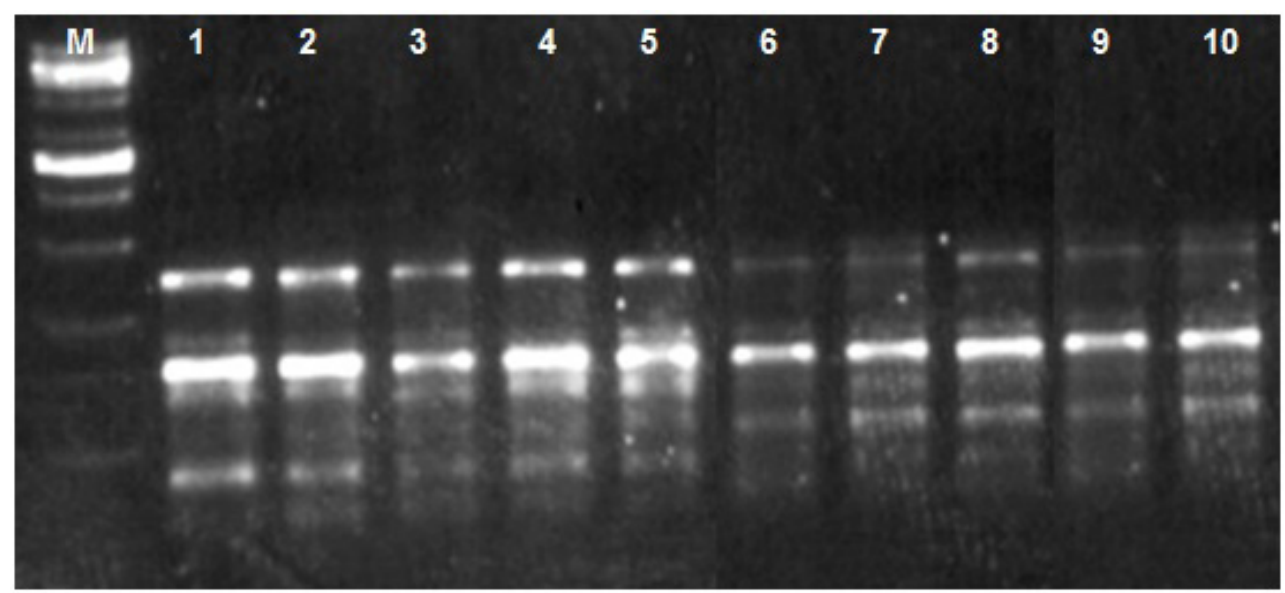

Figure 3. RAPD-PCR of urdbean varieties/lines with primer GLK-07 (lanes 1-10). Lane M=1-kb ladder.

The dendrogram constructed from the similarity matrix showed different clades. Clade 1 comprised population 1 (i.e., M-6206), which was MR; clade No. 2 comprised population 3 (Chakwal Mash PD2-L-V05), 4 (07M003), 6 (M-17), 8 (M-6049-20), and 9 (ES-1), which were grouped as S and HS. Populations 5 (IAM-382-9) and 10 (M-6065-3), which comprised clade No. 3, appeared to be MS and HS. This could be the reason for similarities in their genetic makeup. Clade No. 4 contained the single population 7 (07M006), which was S, and clade No. 5 contained the population 2 (IAM-133), which was MR from screening (Figure 4).

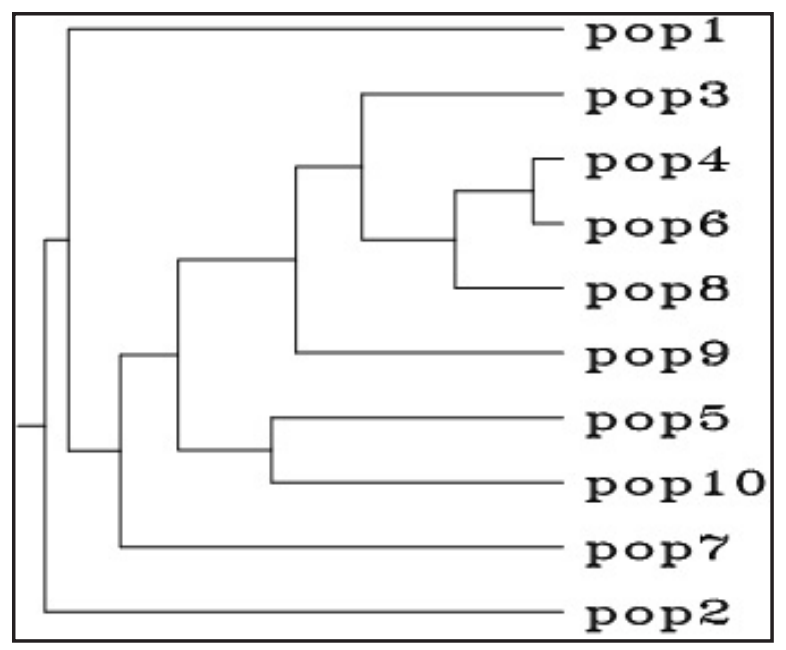

Figure 4. Dendrogram of 10 urdbean genotypes obtained from the similarity matrix. pop $=$ population. 


\section{REFERENCES}

Amadou HI, Bebeli PJ and Kaltsikes PJ (2001). Genetic diversity in Bambara groundnut (Vigna subterranea L.) germplasm revealed by RAPD markers. Genome 44: 995-999.

Anonymous (2009). Economic Survey of Pakistan, Finance and Economic Affairs Division. Govt. of Pakistan, Islamabad, 23. Arulbalachandran D, Mullainathan L, Karthigayan S, Somasundaram ST, et al. (2009). Evaluation of genetic variation in mutants of black gram (Vigna mungo (L.) Hepper) as revealed by RAPD markers. Emir. J. Food Agric. 21: 42-50.

Ashfaq M, Khan MA, Mughal SM, Javed N, et al. (2007). Evaluation of urdbean germplasm for resistance against urdbean leaf crinkle virus. Pak. J. Bot. 39: 2103-2111.

Bashir M and Zubair M (2002). Identification of resistance in urdbean (Vigna mungo) against two different viral diseases. Pak. J. Bot. 34: 49-51.

Bashir M, Mughal SM and Malik BA (1991). Assessment of yield losses due to leaf crinkle virus in urdbean (Vigna mungo (L) Hepper). Pak. J. Bot. 23: 140-142.

Bashir M, Ahmad Z and Ghafoor A (2005). Sources of genetic resistance in mungbean and blackgram against urdbean leaf crinkle virus (ULCV). Pak. J. Bot. 37: 47-51.

Chaudhry MA, Ilyas MB and Ghazanfar MU (2007). Screening of urdbean germplasm for the sources of resistance against urdbean leaf crinkle virus. Mycopathology 5: 1-4.

Dikshit HK, Jhang T, Singh NK, Koundal KR, et al. (2007). Genetic differentiation of Vigna species by RAPD, URP and SSR markers. Biol. Plant. 51: 451-457.

Ghaffor A, Sharif A, Ahmad Z, Zahid MA, et al. (2001). Genetic diversity in blackgram (Vigna mungo L. Hepper). Field Crop Res. 69: 183-190.

Harris SA (1999). RAPD in Systematics - a Useful Methodology. Molecular Systematics and Plant Evolution. Taylor and Francis, London.

Iqbal SM, Ghafoor A, Zubair M and Malik BA (1991). Reactions of urdbean cultivars against leaf crinkle virus disease. J. Agric. Res. 29: 415.

Jinguo H and Brady AV (2003). Target region amplification polymorphism: a novel marker technique for plant genotyping. Plant Mol. Biol. Rep. 21: 289-294.

Kadian OP (1980). Studies on leaf crinkle disease of urdbean (Vigna mungo (L.) Hepper), mungbean (V. radiata (L.) Wilczek) and its control. Ph.D. thesis, Department of Plant Pathology, Haryana Agriculture University, Hisar.

Kaga A, Tomooka N, Egawa Y, Hosaka K, et al. (1996). Species relationships in the subgenus ceratotropis (genus Vigna) as revealed by RAPD analysis. Euphytica. 88: 17-24.

Khan IA, Awan FS, Ahmad A and Khan AA (2004). A modified mini-prep method for economical and rapid extraction of genomic DNA in plants. Plant Mol. Bio. Rep. 22: 89a-89e.

Mignouna HD, Ng NQ, Ikea J and Thottapilly G (1998). Genetic diversity in cowpea as revealed by random amplified polymorphic DNA. J. Genet. Breed. 53: 151-159.

Reddy CH, Tonapi VA, Navi SS and Jayarajan R (2005). Influence of plant age on infection and symptomological studies on urdbean leaf crinkle virus in urdbean (Vigna mungo). Int. J. Agric. Sci. 1: 1-6.

Santalla M, Power JB and Davey MR (1998). Genetic diversity in mungbean germplasm revealed by RAPD markers. Plant Breed. 117: 473-478.

Singh JP (1980). Effect of virus diseases on growth components and yield of mungbean and urdbean. Indian Phythol. 33: 405-408.

Sivaprakash KR, Prashanth SR, Mohanty BP and Parida A (2004). Genetic diversity of black gram (Vigna mungo) landraces as evaluated by amplified fragment length polymorphism markers. Curr. Sci. 86: 1411-1416.

Souframanien J and Gopalakrishna T (2004). A comparative analysis of genetic diversity in blackgram genotypes using RAPD and ISSR markers. Theor. Appl. Genet. 109: 1687-1693.

Souframanien J, Pawar SE and ucha AG (2002). Genetic variation in gamma ray induced mutants in blackgram as revealed by RAPD and ISSR markers. Indian J. Genet. 62: 291-295.

Williams JG, Kubelik AR, Livak KJ, Rafalski JA, et al. (1990). DNA polymorphisms amplified by arbitrary primers are useful as genetic markers. Nucleic Acids Res. 18: 6531-6535.

Yee E, Kidwell KK, Sills GR and Lumpkin TA (1999). Diversity among selected Vigna angularis (adzuki) accessions on basis of RAPD and AFLP markers. Crop Sci. 39: 268-275. 